DOI:10.22591/magyurol.2018.1.sarlosd.8

\title{
Új laparoszkópos vesetumor-reszekció gyakorló modell kifejlesztése
}

\author{
Sarlós Donát Péter dr., Czétány Péter med.
}

PTE KK, Urológiai Klinika, Pécs (igazgató: Szántó Árpád dr.)

\section{ÖSSZEFOGLALÁS}

Célkitüzés: A vesedaganatok laparoszkópos reszekciójának gyakorlására szolgáló eszközök nem állnak rendelkezésre széles körben. Munkánk célja egy bárki számára elérhető parciális nephrectomia (PN) gyakorlómodell kifejlesztése volt.

Anyagok és módszer: A modell alapja közepes sürüségű, nyiltt pórusszerkezetű poliuretán hab, amire szilikon tömítőanyagból egy tumort készítünk. A daganat vérellátását végző ereket latex katéterrel, a vese üregrendszerét latex gumikesztyü ujjával szimuláltuk. A pelvitrainerbe helyezett modell hasznosságát orvostanhallgatók bevonásával teszteltük, akik összesen 160 szimulált PN-t végeztek el. A beavatkozások pontos dokumentációja mellett a hallgatók laparoszkópos ügyességének fejlődését virtuális valóság szimulátor segítségével vizsgáltuk.

Eredmények: A modellen élethüen gyakorolhatók a PN egyes lépései, mint a tumor kimetszése, a tumoralap képleteinek ellátása és a veseparenchyma zárása, mindeközben mütéti terület vérzése és vizeletes ázása is szimulálható. Több modell egyidejű elkészitése esetén egy modell anyagára átlagos minőségü alapanyagokból körülbelül 200 Ft, és körülbelül 7,5 perc alatt elkészithető. A modell tesztelése során szignifikáns javulást észleltünk a reszekciós időben, (746 \pm 338 s vs. $244 \pm 123$ s, $p<0,01)$, a behelyezett öltések számában (1 [0-2] vs. 4,5 [2-5,5], $\mathrm{p}<0,05)$ és a vérveszteségben

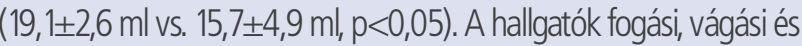
öltési ügyessége javult, a felesleges mozgásaik csökkentek.

Következtetések: Az általunk készített modell hasznosságát kisérleteink során igazoltuk. Reményeink szerint a jövőben az urológiai készségfejlesztésben kollégáink sikerrel használják majd.

\section{KULCSSZAVAK}

VESERESZEKCIÓ, LAPAROSZKÓPIA, GYAKORLÓMODELL

\section{Bevezetés}

A radikális és a parciális nephrectomia (PN) onkológiai eredményessége hasonló. A mai európai irányelvek szerint a vesedaganatok eltávolitásakor az olykor nagyobb kihívást jelentő nephron-kímélő
Levelezési cím:

Dr. Sarlós Donát Péter

7621 Pécs, Munkácsy M. u. 2.

E-mail:

donat.peter.sarlos@gmail.com

\section{Development of a laparoscopic partial nephrectomy training model}

\section{SUMMARY}

Objective: Urologists seek opportunities for the development of surgical skills. Our objective was the development of a laparoscopic partial nephrectomy (PN) training model.

Methods: The base of the PN model is polyurethane foam, in which a silicone artificial tumour is implanted. Latex Foley catheter and examination glove fingers are used to simulate vessels and collecting system. Sixteen medical students, who were novice in laparoscopy tested the model, performing a total of 160 PNs. CAE LapVR laparoscopic virtual-reality surgical simulator was used to test laparoscopic dexterity before and after the training.

Results: The model's mechanic properties show good similarity with the normal human kidney. The steps of the PN operation can be trained, bleeding and urine leakage can be simulated. The price of the materials for one model is under 1 Euro and can be self-produced in less than 10 minutes. During the testing candidates showed a significant progression in resection time (746 \pm 338 s vs. $244 \pm 123 s, p<0.01)$, number of stitches placed (1 [0-2] vs. 4.5 [2-5.5], $p<0.05)$ and post-operative bleeding (19.1 $\pm 2.6 \mathrm{ml}$ vs. $15.7 \pm 4.9 \mathrm{ml}, \mathrm{p}<0.05)$. Laparoscopic peg transfer, cutting and stitching dexterity has improved, along with significant reduction of unnecessary movements.

Conclusions: We created a widely available and low cost model for PN training that has been proven to better laparoscopic surgical skills. We hope it will help advance skill training in urology and flatten PN learning curves.

\section{KEYWORDS}

PARTIAL NEPHRECTOMY, LAPAROSCOPY, TRAINING MODEL

sebészetre kell törekedni (1). A sebészeti szimulációs oktatás jelentősen javítja a gyakorolt beavatkozások tanulási görbéjét (2). A laparoszkópos PN gyakorlására több modellt kifejlesztettek korábban, azonban egyik sem elérhetó széles körben. Munkánk célja egy mindenki számára rendelkezésre âlló modell kifejlesztése volt. 


\section{Anyagok és módszer}

A modell elkészítéséhez közepes súrüségú poliuretán habmatracot, 12 Ch-es latex Foley-katétert, latex gumikesztyút, és polisziloxán (szilikon) tömítőanyagot használtunk fel. A poliuretán alapot veseformájúra munkáltuk meg úgy, hogy az $13 \pm 0,5 \mathrm{~cm}$

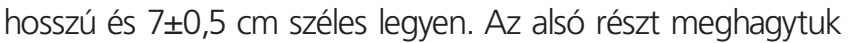
laposnak, annak érdekében, hogy a gyakorló doboz aljához könnyebb legyen hozzárögzíteni. Standardizált predilekciós helyeken a vese pólusától 1,5 cm-re, a ventralis felszínen 2,5 cm-es félgömb formájú részt vágtunk ki a modellből, ez jelképezte a tumor alapját. Két elöre meghatározott pontban a tumoralap középpontjától 0,5 cm távolságban járatokat alakítottunk ki. Ezekbe egy körülbelül 7 cm-es katéterdarabot és egy gumikesztyú levágott ujját ragasztottuk be a járatba előre beadagolt átlátszó szilikonnal. Előbbi egy érképletet, utóbbi a mútét során megnyíló veseüregrendszert modellezi. A katéteren és a gumikesztyúujjon keresztül vérzés és vizeletes ázás szimulálása céljából, infúziós szerelék segítségével folyadék áramoltatható át. Ezt követően a tumoralapot púposan feltöltöttük színes szilikonnal, amit körülbelül 50\%-ban endophytikus gömb formájúra formáztunk, ez jelképezte a daganatot (R.E.N.A.L. score 6a, PADUA score 7) $(3,4)$. A szilikon tömítőanyagnak az optimális kötöttség eléréséhez körülbelül 48 órára van szüksége. A modell alapjára erős kétoldalú szivacsos szigetelőszalagot helyeztünk, amit a modellhez két külön öltéssel is hozzárögzítettünk. Ennek segítségével a modell a pelvitrainer aljához rögzíthető.

A modell tesztelését tizenhat önként jelentkező orvostanhallgató bevonásával végeztük. Mindnyájan tantervük részeként a sebészeti mútéttant alapszinten elsajátították, ahol a laparoszkópia alapjait megismerték. További laparoszkópos tapasztalattal nem rendelkeztek. A kísérlet során öt nap alatt fejenként összesen tíz szimulált laparoszkópos parciális nephrectomiát kellett elvégezniük, amikre egyenként 20 perc időtartam állt rendelkezésükre. Ezen idő alatt kellett végrehajtaniuk a daganat kimetszését, és behelyezni egy tovafutó mély öltéssort úgy, hogy az legalább öt öltésből álljon, ezek közül kettővel az érképletet, kettóvel pedig az üregrendszert igyekezzenek zárni. A rendelkezésre álló laparoszkópos eszközök a Maryland-disszektor, Metzenbaum-olló és két tüfogó voltak. A varróanyag egy 26 mm 1⁄2-es vágó élű tüvel ellátott 3-0 polipropilén fonal volt, ami $19 \mathrm{~cm}$ hosszú volt, és a végére egy $1 \times 1$ cm-es összehajtogatott gézlapot csomóztunk, hasonlóan a korábban Klinikánk laparoszkópos munkacsoportja által bemutatott pécsi módszerhez (5) (1. ábra). A varratsor hatékonyságának vizsgálatához a modellen található katéterhez és kesztyúujjhoz infúziós szereléket csatlakoztattunk és $50 \mathrm{H}_{2} \mathrm{O}$
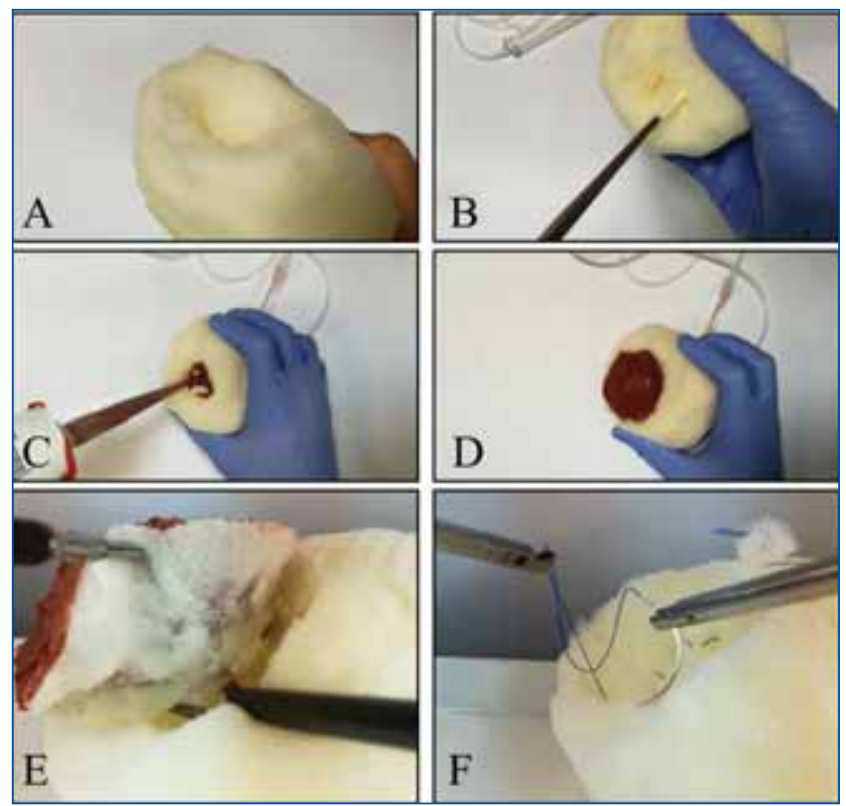

1. Ábra: A MOdell elKÉSZítése ÉS hasznÁlatA

A: Az alap megFORMÁlÁsa B: ÉRKÉPLET ÉS ÜREGRENDSZER BERAGASZTÁSA; C: TUMORMASSZA KIALAKÍTÁSA;

D: ELKÉSZÜLT MODELL; E: SZIMULÁLT VESETUMOR-RESZEKCIÓ; F: TUMORALAP ELLÁTÁSA

cm-es nyomással folyadékot vezettünk bele. A szimulált vérzés és vizeletes ázás mennyiségének mérését 15 másodpercig folytattuk minden esetben. A laparoszkópos készségeket a kísérlet előtt és után CAE LapVR laparoszkópos virtuális valóság szimulátorban mértük fel.

Az adatokat Microsoft Excel táblázatokban összesítettük, elemzésükre IBM SPSS 22.0 programcsomagot használtunk. A változók összehasonlítására páros t-próbát, Mann-Whitney-próbát, vagy Wilcoxon-féle előjeles rangösszeg próbát használtunk.

\section{Eredmények}

Több modell egyidejű elkészítésekor az egy darab elkészítéséhez szükséges idő körülbelül 7,5 perc, a költségek összesen körülbelül 200 Ft-ot tesznek ki. A felhasznált szivacs anyag kedvező mechanikai tulajdonságokkal bír, könnyedén vágható ollóval, megfelelően rögzül hozzá a szilikon ragasztó és jól tartja az öltéseket. A kiadások kalkulációját az 1. táblázatban foglaltuk össze.

1. TÁBLÁZAT: A MOdELL ELKÉSZÍTÉSÉVEL KAPCSOLATOS KIADÁSOK ÖSSZEFOGLALÁSA

\begin{tabular}{lccc}
\multicolumn{1}{c}{ Anyag } & Modellek száma & Hozzávetöleges ár (Ft) & Modellenkénti ár (Ft/db) \\
\hline Poliuretán habmatrac & 225 & 11000 & 49 \\
Szilikon & 16 & 1300 & 81 \\
Gumikesztyű & 10 & 100 & 10 \\
Foley-katéter & 3 & 260 & 87 \\
Összesen & & & 227
\end{tabular}



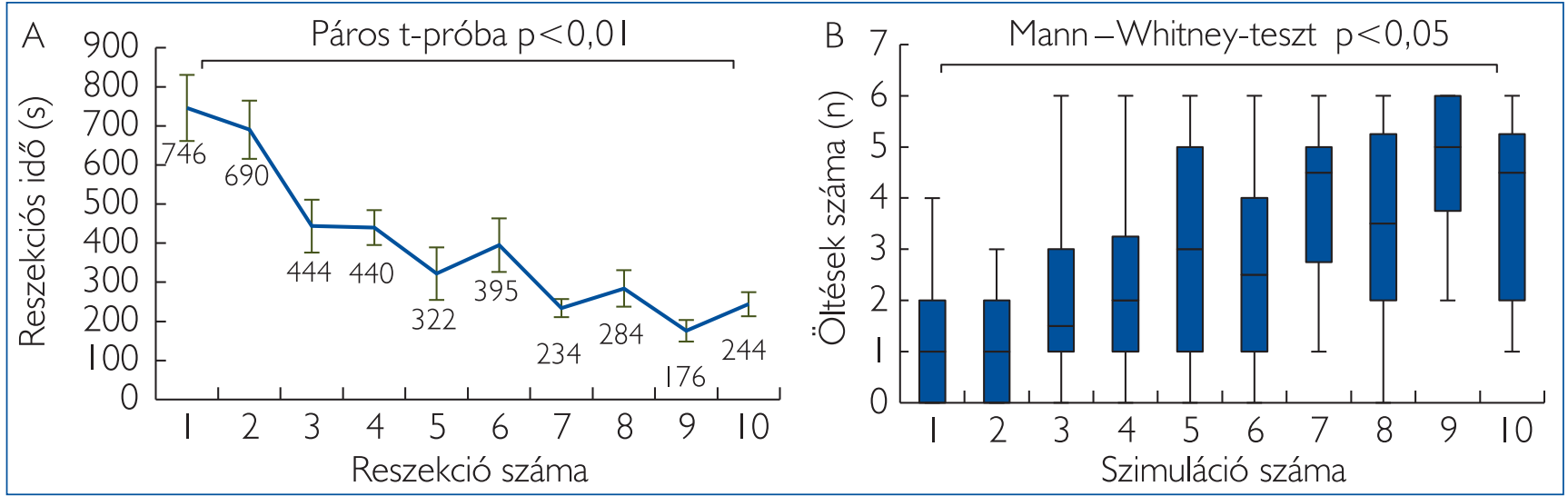

2. Ábra: A reszekciós idő (A) És a behelyezett öltések számÁnak (B) alakulása a kísérlet Során

A modell tesztelése során az első és a tizedik beavatkozást öszszehasonlítva jelentősen csökkent a kimetszéshez szükséges idő (746 \pm 338 s vs. $244 \pm 123$ s, p<0,01) (2. ábra). A kísérlet előrehaladtával jelentősen nőtt a behelyezett öltések száma (1 [0-2] vs. 4,5 [2-5,5] p<0,05). A kiértékelés során az első, és a tizedik mintát összehasonlítva jelentősen csökkent a szimulált vérzés

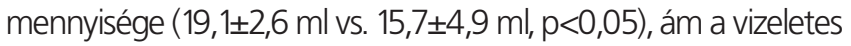

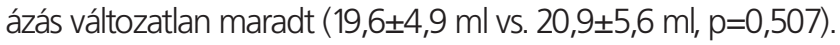
A laparoszkópos szimulátoron végzett mérések szignifikáns javulást mutattak mind a peg transzfer és a vágási feladatok végrehajtásában, ahol nemcsak a feladatok végrehajtásához szükséges idő, hanem a felesleges kézmozgások és a feladat közbeni hibák is jelentősen csökkentek. A felmérés eredményeit a 2. táblázatban foglaltuk össze.

\section{Megbeszélés}

A vesedaganatok prevalenciája világszerte növekszik, eközben a modern képalkotó módszereket egyre szélesebb körben alkalmazzák. Az incidentálisan felfedezett kisméretû vesetérfoglalások száma évről évre magasabb, emiatt a minimálisan invazív technikával végzett parciális nephrectomiák száma meg- emelkedett. Az ilyen mútétek elvégzéséhez szükséges mútéttechnikai készségeket célszerū minél korábban és biztonságos környezetben elsajátítani. Több mint tíz éve léteznek modellek a parciális nephrectomia gyakorlásához. Az első készítmények sertés veséjét használták alapnak (6-10). Azon kívül, hogy a veseüregrendszer morfológiája különbözik, ez egy rendkívül valósághú szimulációt tesz lehetővé, akár in vivo is. A hátránya a disznóvesének az esetleges beszerzés, a romlandóság és annak a nehézsége, hogy a parenchymába egy arteficiális tumort stabilan rögzítsünk (11).

Több vesemodellt készítettek a háromdimenziós nyomtatás segítségével, ezek ma a legmodernebb készítmények. Ezek felhasználási területébe a gyakorláson kívül a mútéti tervezés, és a betegek pontosabb felvilágosítása is beletartozik (12-19). Egy részüknél a nyomtatóval a teljes modellt elkészítik, másoknál egy negatív öntőformát képeznek. A képalkotó szoftverekkel való fúzió technológiájával esetspecifikus modellek készíthetők. A módszer hátránya, hogy napjainkban kevéssé elterjedt és nagyon költséges.

A virtuális valóság trénerek fejlesztésével lehetőség nyílik olyan szoftverek kifejlesztésére, amiken a parciális nephrectomia is gyakorolható szcenárió lehet (20). Jelenleg ezek drágák és korlátozott a hozzáférhetőségük.

\section{TÁbLÁZAT: A LAPAROSZKÓPOS SZIMULÁTORRAL VÉGZETT MÉRÉSEK ADATAI A MODELLEN TÖRTÉNT GYAKORLÁS ELŐTT ÉS} UTÁN (SD: SZÓRÁS, IQR: INTERKVARTILIS TERJEDELEM)

\begin{tabular}{lccc}
\multicolumn{1}{c}{ Feladatok adatai } & Gyakorlás elött & Gyakorlás után & p-értékek \\
\hline Peg transzfer idő, s (SD) & $170,3(47,7)$ & $116,7(33,7)$ & $\mathrm{p}<0,01$ \\
\hline Peg transzfer kézmozgások, mm (SD) & $6673(1714)$ & $5064(1117)$ & $\mathrm{p}<0,05$ \\
Leejtett pegek száma, n /IQR/ & $1(0-2)$ & $0(0-1)$ & $\mathrm{p}<0,05$ \\
Vágás idő, s (SD) & $312,5(92,9)$ & $159,8(40,5)$ & $\mathrm{p}<0,01$ \\
Vágás kézmozgások, mm (SD) & $7307(3187)$ & $4173(924)$ & $\mathrm{p}<0,01$ \\
Elhibázott vágások száma, n /IQR/ & $12,5(5-18)$ & $6,5(2-10)$ & $\mathrm{p}<0,05$ \\
Varrási idő, s (SD) & $170,6(120,2)$ & $97,7(68,7)$ & $\mathrm{p}=0,079$ \\
Varrási kézmozgások, mm (SD) & $5024(4006)$ & $3347(1930)$ & $\mathrm{p}=0,192$ \\
Leejtett túk száma, $\mathrm{n} / \mathrm{IQR} / \mathrm{0}$ & $0(0-2)$ & $0(0-1)$ & $\mathrm{p}=0,440$
\end{tabular}


Munkacsoportunkkal egy olyan gyakorlómodellt mutatunk be, aminek a fő előnyei a könnyű és olcsó elkészithetőség, és a jó eltarthatóság. A modell megfeleló élethúség mellett intraoperatív vagy posztoperatív vérzés és vizelet ázás szimulációjára is alkalmas. A kutatásunkban részt vevő hallgatók jelentős fejlődést mutattak a tumor kimetszésének idejét $(p<0,01)$, az öltések számát $(p<0,05)$ és a posztoperatív vérzést illetően $(p<0,05)$. A javuló varrási technika ellenére a szimulált vizeletes ázásban nem tapasztaltunk javulást. Ennek okát abban látjuk, hogy a modellbe ágyazott gumikesztyúujj víztartó bezárása az utasításaink szerint behelyezett két öltéssel csak kivételes esetekben sikerül. Kísérleteink során az irodalomban elsőként használtunk mérőeszközként laparoszkópos virtuális valóság trénert. Ez a módszer a feladatok végrehajtását és a kísérleti egyének fejlődésének precíz dokumentációját teszi lehetővé.
Bízunk benne, hogy többen kedvet kapnak hasonló gyakorlóeszközök készítéséhez, és az urológus szakorvosképzésben a sebészeti szimulációs oktatás tárháza tovább bővülhet.

\section{Köszönetnyilvánítás}

A szerzők köszönetüket fejezik ki Dr. Pusztai Csabának, Dr. Bányai Dánielnek, Hargitainé Óbert Erzsébetnek és Pandúr Melindának a PTE KK Urológiai Klinikáról, Dr. Varga Tamásnak és Baranyainé Boskovics Gabriellának a PTE KK Szülészeti és Nőgyógyászati Klinikáról, Dr. Varga Péternek és Jakabovics Adriennek a PTE ÁOK Sebészeti Oktató és Kutató Intézetből, Dr. Maróti Péternek a PTE ÁOK Sebészeti Szimulációs Központból és valamennyi, a kísérletben részt vevő hallatónak a munkában nyújtott segítségükért.

\section{Irodalom}

1. Ljungberg B, Albiges L, Bensalah K, et al. EAU Guidelines on Renal Cell Carcinoma. EAU Guidelines. Edn. presented at the EAU Annual Congress London: 2017. p. 22-40.

2. Chow AK, Sherer BA, Yura E et al. Urology Residents' Experience and Attitude Toward Surgical Simulation: Presenting our 4-Year Experience With a Multi-institutional, Multi-modality Simulation Model. Urology 2017; 109: 32-37. https://doi.org/10.1016/j.urology.2017.05.037

3. Kutikov A, Uzzo RG. The R.E.N.A.L. nephrometry score: a comprehensive standardized system for quantitating renal tumor size, location and depth. J Urol 2009; 182: 844-853. https://doi.org/10.1016/j. juro.2009.05.035

4. Ficarra V, Novara G, Secco $S$ et al. Preoperative aspects and dimensions used for an anatomical (PADUA) classification of renal tumours in patients who are candidates for nephron-sparing surgery. Eur Urol 2009; 56: 786-793. https://doi.org/10.1016/j.eururo.2009.07.040

5. Pusztai CS, Bagheri F, Bányai $D$, et al. Laparoszkópos parciális nephrectomia - A pécsi módszer. Magyar Urológia 2013; 25 (1): 12-19

6. Hidalgo J, Belani J, Maxwell K et al. Development of exophytic tumor model for laparoscopic partial nephrectomy: technique and initial experience. Urology 2005; 65: 872-876. https://oi.org/10.1016/j.urology.2004.12.002

7. Yang B, Zeng Q, Yinghao $S$ et al. A novel training model for laparoscopic partial nephrectomy using porcine kidney. J Endourol 2009; 23: 2029-2033. https://doi.org/10.1089/end.2009.0245

8. Ames $C D$, Vanlangendonck $R$, Morrissey $K$ et al. Evaluation of surgical models for renal collecting system closure during laparoscopic partial nephrectomy. Urology 2005; 66: 451-454. https://doi.org/10.1016/j.urology.2005.03.033

9. Rouach Y, Timsit MO, Delongchamps NB et al. [Laparoscopic partial nephrectomy: urology resident learning curve on a porcine model]. Prog Urol 2008; 18: 344-350. https://doi.org/10.1016/j.purol.2008.03.009

10. Eun D, Bhandari A, Boris R et al. A novel technique for creating solid renal pseudotumors and renal vein-inferior vena caval pseudothrombus in a porcine and cadaveric model. J Urol 2008; 180: 1510-1514. https:// doi.org/10.1016/j.juro.2008.06.005

11. Hung AJ, Ng CK, Patil MB et al. Validation of a novel robotic-assisted partial nephrectomy surgical training model. BJU Int 2012; 110: 870874. https://doi.org/10.1111/.1464-410X.2012.10953.x

12. Porpiglia F, Bertolo R, Checcucci E et al. Development and validation of 3D printed virtual models for robot-assisted radical prostatectomy and partial nephrectomy: urologists' and patients' perception. World J Urol 2018; 36(2): 201-207. https://doi.org/10.1007/s00345-017-2126-1

13. Fernandez A, Chen E, Moore J et al. A phantom model as a teaching modality for laparoscopic partial nephrectomy. J Endourol 2012; 26: 1-5. https://doi.org/10.1089/end.2011.0131

14. Abdelshehid CS, Quach S, Nelson C et al. High-fidelity simulation-based team training in urology: evaluation of technical and nontechnical skills of urology residents during laparoscopic partial nephrectomy. J Surg Educ 2013; 70: 588-595. https://doi.org/10.1016/j.jsurg.2013.04.009

15. Zhang Y, Ge HW, Li NC et al. Evaluation of three-dimensional printing for laparoscopic partial nephrectomy of renal tumors: a preliminary report. World J Urol 2016; 34: 533-537. https://doi.org/10.1007/s00345015-1530-7

16. Bernhard JC, Isotani S, Matsugasumi T et al. Personalized 3D printed model of kidney and tumor anatomy: a useful tool for patient education. World J Urol 2016; 34: 337-345. https:/doi.org/10.1007/s00345015-1632-2

17. von Rundstedt FC, Scovell JM, Agrawal S et al. Utility of patient-specific silicone renal models for planning and rehearsal of complex tumour resections prior to robot-assisted laparoscopic partial nephrectomy. BJU Int 2017; 119: 598-604. https://doi.org/10.1111/bju. 13712

18. Maddox MM, Feibus A, Liu J et al. 3D-printed soft-tissue physical models of renal malignancies for individualized surgical simulation: a feasibility study. J Robot Surg 2017. https://doi.org/10.1007/s11701-017-0680-6

19. Golab A, Smektala T, Kaczmarek K et al. Laparoscopic Partial Nephrectomy Supported by Training Involving Personalized Silicone Replica Poured in Three-Dimensional Printed Casting Mold. J Laparoendosc Adv Surg Tech A 2017; 27: 420-422. https:/doi.org/10.1089/ lap.2016.0596

20. Hung AJ, Shah SH, Dalag L et al. Development and Validation of a Novel Robotic Procedure Specific Simulation Platform: Partial Nephrectomy. J Urol 2015; 194: 520-526. https://doi.org/10.1016/j.juro.2015.02.2949 